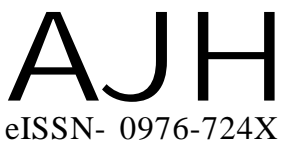

Received : 13.09.2016

Revised : 01.11.2016

Accepted : 15.11.2016

Members of the Research Forum

Associated Authors:

${ }^{1}$ Department of Horticulture, Faculty

of Agriculture, Annamalai

University, Annamalai Nagar,

CHIDAMBARAM (T.N.) INDIA

Author for correspondence : E. ARIVAZHAGAN

Department of Horticulture, Faculty

of Agriculture, Annamalai

University, Annamalai Nagar,

CHIDAMBARAM (T.N.) INDIA
THEASIAN JOURNALOF HORTICULTURE

Volume 11 | Issue 2 | December, 2016 | 344-348

Visit us -www.researchjournal.co.in

RESEARCH PAPER

DOI : $10.15740 / \mathrm{HAS} / \mathrm{TAJH} / 11.2 / 344-348$

\title{
Evaluation of sapota cultivars for quality characters
}

\section{N. RAMADOSS AND E. ARIVAZHAGAN ${ }^{1}$}

ABSTRACT : An investigation was carried out at the Department of Horticulture, Faculty of Agriculture, Annamalai University during 2014-2015 to evaluate the performance of eight sapota cultivars, viz., PKM 1, Virudhunagar, Kirthibarthi Round, Cricket Ball, CO 2, Pala, Oval and Kirthibarthi Oval was studied in two seasons viz., February to April (peak season I) and July to September (peak season II). The experiment was laid out in Randomized Block Design (RBD) in three replications. With regard to quality characters, the cultivar Virudhunagar was found to be superior followed by $\mathrm{CO} 2$.

KEY WORDS : Sapota, Evaluation, Quality characters

HOW TO CITE THIS ARTICLE : Ramadoss, N. and Arivazhagan, E. (2016). Evaluation of sapota cultivars for quality characters. Asian J. Hort., 11(2) : 344-348, DOI : 10.15740/HAS/TAJH/11.2/344348. 